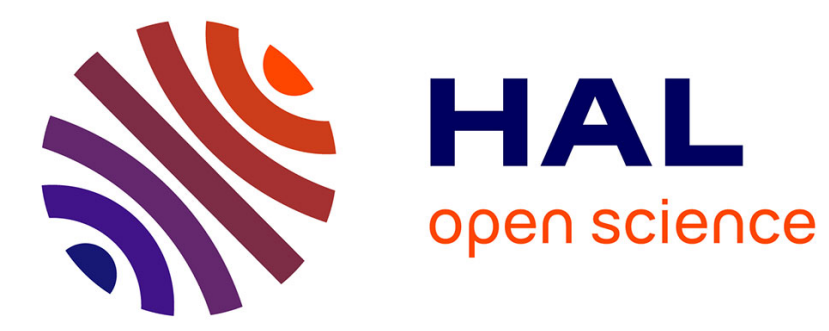

\title{
Random mutagenesis of Peptide aptamers as an optimization strategy for inhibitor screening.
}

Nathalie Bouquier, Sylvie Fromont, Anne Debant, Susanne Schmidt

\section{To cite this version:}

Nathalie Bouquier, Sylvie Fromont, Anne Debant, Susanne Schmidt. Random mutagenesis of Peptide aptamers as an optimization strategy for inhibitor screening.. Methods in Molecular Biology, 2012, 928, pp.97-118. 10.1007/978-1-62703-008-3_8. hal-00731520

\section{HAL Id: hal-00731520 \\ https://hal.science/hal-00731520}

Submitted on 13 Sep 2012

HAL is a multi-disciplinary open access archive for the deposit and dissemination of scientific research documents, whether they are published or not. The documents may come from teaching and research institutions in France or abroad, or from public or private research centers.
L'archive ouverte pluridisciplinaire HAL, est destinée au dépôt et à la diffusion de documents scientifiques de niveau recherche, publiés ou non, émanant des établissements d'enseignement et de recherche français ou étrangers, des laboratoires publics ou privés. 
Peptide aptamer optimization

\title{
Random mutagenesis of peptide aptamers
}

\section{as an optimization strategy for inhibitor screening}

\author{
Nathalie Bouquier, Sylvie Fromont, Anne Debant and Susanne Schmidt \\ Centre de Recherche de Biochimie Macromoléculaire \\ CNRS $\square$ UMR 5237 \\ Universités Montpellier I et II \\ 1919 Route de Mende \\ 34293 Montpellier Cedex 5, FRANCE
}

\section{Corresponding authors:}

Susanne Schmidt, PhD: susanne.schmidt@crbm.cnrs.fr

Anne Debant, PhD : anne.debant@erbm.cnrs.fr

Centre de Recherche de Biochimie Macromoléculaire

CRBM -- CNRS UMR 5237

1919 Route de Mende

34293 Montpellier Cedex 5, FRANCE 


\section{Summary}

Accumulating work over the past decade has shown that peptide aptamer screening represents a valid strategy for inhibitor identification that can be applied to a variety of different targets. Because of the screening method in cells and the highly combinatorial libraries available, this approach yields rapidly highly specific candidate inhibitors. Once a hit peptide has been identified, its interaction strength and affinity towards its target protein can be optimized even more, in order to increase its inhibition efficiency when subsequently applied in vivo. A condition to a successful optimization is that gain of inhibition strength should not result in loss of specificity.

Here we present a simple method for peptide aptamer optimization, which can be achieved by PCRbased random mutagenesis combined with a selection screen in yeast using a strong selective drug. The rationale of this approach, which has proven valid and efficient, is that stronger interaction in yeast will also lead to stronger inhibition. Our optimization method is effective, without loss of specificity, which is of a great importance for the discovery of inhibitors that target specific proteinprotein interactions.

\section{Key words}

Peptide aptamers, PCR-based mutagenesis, yeast two-hybrid, fluorescent GEF assay, inhibitor screening. 


\section{Introduction}

Peptide aptamers are short peptides, generally composed of 20 random amino acids, which are conformationally constrained by a scaffold protein such as bacterial Thioredoxin A (TrxA), and which are commonly used as disrupters of protein-protein interactions (1). They have been widely used over the past decade as inhibitors of various intracellular targets, including cell cycle control and cell survival proteins, but also as antiviral and antibacterial agents $(2,3)$. They have also been applied to dissect and inhibit intracellular signaling pathways that regulate cellular proliferation, such as EGFR or Ras signaling (4). Our lab has used this technology to specifically target one of the Rho guanine nucleotide factor (RhoGEF) domains of Trio, which activates the small monomeric GTPase RhoA (5, б). We initially isolated the peptide aptamer TRIP $\alpha$ as an inhibitor of Trio, using a classical twohybrid screening (5). Subsequently, using the optimization strategy described in this chapter, we were able to convert this original aptamer into an even more potent inhibitor of Tgat, the oncogenic isoform of Trio, which activates RhoA and which has been isolated from patients with Acute T-cell Leukemia (ATL) (7). This novel TRIP $\alpha$ derived peptide targets Tgat GEF activity in vitro in a highly specific manner and strongly reduces its oncogenic properties in vivo, most remarkably by decreasing foci formation and tumor development in nude mice (6). Interestingly, although TRIP $\alpha$ and the TRIP-like peptides were initially selected as inserted in the TrxA scaffold, they remained equally active as linear peptides.

Peptide aptamers present interesting advantages over other classes of inhibitory molecules, mainly because of their simple design and their high degree of binding specificity, which enables them to discriminate between closely related proteins within a functional family. As compared to an approach by complete knock-down of the protein (such as siRNA), peptide aptamers recognize selectively a single domain of a protein, thus interfering with one specific function, without affecting others. This is of great advantage when targeting complex proteins harboring numerous domains. But most remarkably, these unbiased and highly combinatorial proteins are screened and designed to function inside living cells. 
High selectivity is clearly the major advantage of the peptide aptamer technology. We show here that inhibition strength may even be enhanced, which is of particular importance for the use of the peptides in in vivo systems, as demonstrated by Bouquier and colleagues (6). In this chapter, we present a simple method for peptide aptamer optimization, i.e. increased inhibition potential towards the target protein, which can be achieved by random PCR-based mutagenesis combined with a selection screen in yeast using a strong selective drug (Figure 1). The rationale of this approach, which has proven valid and efficient, is that stronger interaction in yeast will also lead to stronger inhibition. The peptide aptamer isolated in the initial screen, and selected for its specific inhibition of the target protein, is used as a template for PCR-based random mutagenesis, in order to create a new peptide aptamer library derived from this peptide, which can then be screened for stronger interaction with the bait. PCR is performed using specific conditions that vary from the classical PCR, in order to maximize misincorporation of base pairs ( $\boldsymbol{8})$. High concentrations of $\mathrm{MgCl}_{2}$ and $\mathrm{MnCl}_{2}$ are used to stabilize noncomplementary base pairs and to diminish the template specificity of the Taq DNA polymerase, respectively. An excess of dCTP and dTTP (versus dATP and dGTP) is used to promote misincorporation. An excess of Taq DNA polymerase is added to promote chain-extension beyond positions of base mismatch. Finally, serial dilutions between PCR cycles are performed to avoid predominance of a given mutation. Several independent mutagenic PCRs are performed in parallel and are then pooled prior to amplification by classical PCR, in order to maximize the variation of the introduced mutations.

The PCR fragments are subsequently subcloned into the appropriate two-hybrid vector, to create a mutant peptide library that can then be screened in a classical two-hybrid system, with the bait of interest. The complexity of the library to be obtained should be calculated as follows, for a 20 amino acid peptide encoded by $60 \mathrm{bp}$ : for each base pair, there are three possibilities for introducing a mutation (for example, an A can be mutated into $\mathrm{C}, \mathrm{G}$ or $\mathrm{T}$ ). This means that for 1 mutation/peptide approximately 180 clones $(3 \times 60)$ are required. Thus, in order to obtain a relevant number of approximately three mutations/insert, one needs a library with a complexity of $5.8 \times 10^{6}$ and one should 
ideally screen approximately this number of clones to get a representative number of different mutations (keeping in mind that this includes also silent mutations and premature stop codons). For the yeast-two hybrid screening, we have chosen a system in which the threshold of interaction detection can be modulated by the concentration of the 3-aminotriazole (3-AT) drug. This drug prevents Histidine synthesis, and thus only strong interactors, which will efficiently activate the Histidine reporter gene, will allow yeast to grow (Figure 2). The concentration of 3-AT to be used varies for each aptamer/bait couple, and has to be determined in a pilot yeast transformation assay prior to the actual large scale mutant peptide library screening.

Following the mutant aptamer library screening, positive clones are picked on plates containing a concentration of 3-AT at which no interaction with the original peptide was detected anymore, and plasmid DNA from these clones is re-transformed into yeast, in order to confirm strong binding to the bait protein under these stringent conditions. Sixty clones is a reasonable number to start with, considering possible redundancy and subsequent processing of clones.

Finally, the new aptamers obtained should be further processed in order to be tested in the same relevant biological assay as the initial aptamer from which they were derived. As an example, we present at the end of this chapter an in vitro GEF assay, in which we tested the optimized TRIP-like peptides we have obtained targeting the RhoGEF Tgat. We show that they are indeed at least 2 to 6 fold more efficient than the original peptide TRIP $\alpha$ in inhibiting Tgat exchange activity towards RhoA. 


\section{Materials}

\subsection{PCR-based random mutagenesis}

\subsubsection{PCR-based mutagenesis}

Solutions and reagents

1. Taq DNA Polymerase (Promega) and 10x Taq polymerase Buffer

2. $5 \sqsubset$ and $3 \square$ PCR primers: primers should be chosen annealing to flanking regions of the peptide coding sequence. Coding sequence overlapping base pairs will not be mutated.

3. PCR premix: mix $125 \mu 110 x$ Taq Pol buffer, $1.25 \mu 1 \mathrm{MgCl}_{2} 1 \mathrm{M}, 2.5 \mu 1 \mathrm{dATP} 100 \mathrm{mM}, 2.5 \mu 1$ dGTP 100mM, $12.5 \mu 1 \mathrm{dCTP} 100 \mathrm{mM}, 12.5 \mu 1 \mathrm{dTTP} 100 \mathrm{mM}, 31.25 \mu 15$ primer $20 \mu \mathrm{M}, 31.25 \mu 1$ $3 \sqsubset$ primer $20 \mu \mathrm{M}$, qsp d $\mathrm{d}_{2} \mathrm{O} 1 \mathrm{ml}$.

4. 3M Sodium Acetate, $\mathrm{pH} 5.2$

5. $95 \%$ and $70 \%$ Ethanol

\subsubsection{PCR-amplification of mutated inserts}

Solutions and reagents

1. Pfu DNA polymerase (Promega) and 10x Pfu polymerase Buffer

2. $10 \mathrm{mM}$ dNTP mix (Invitrogen)

3. $5 \sqsubset$ and $3 \square$ PCR primers (same as in Section 2.1.1)

4. Appropriate restriction enzymes and their corresponding 10x reaction buffer (New England Biolabs)

5. Qiaquick Gel extraction Kit (Qiagen)

\subsection{Construction of mutant aptamer yeast library}

\subsubsection{Ligation and large scale transformation into competent E.coli}

Strains and plasmids

1. Plasmid pPC86-Gal4AD-Thrx (Trp selection marker): we designed a modified version of the commercially available pPC86-Gal4AD plasmid in which we inserted the TrxA coding gene. Plasmid map can be obtained upon request. 
2. E. coli EP-Max 10B Electroporation $\mathrm{F} \square$ mcrA $\Delta$ (mrr-hsdRMS-mcrBC) 80dlacZDM15

$\Delta$ lacX74 deoR recA1 endA1 araD139 $\Delta($ ara, leu) 7697 galU galK rpsL nupG

Solutions and reagents

1. Appropriate restriction enzymes and their corresponding 10x buffers (New England Biolabs)

2. Alkaline Phosphatase (AP) 1U/ $\mu$ l (Roche Diagnostics) + 10x dephosphorylation buffer

3. Phenol/Chloroform (Invitrogen)

4. Reagents for $\mathrm{NaAC} /$ ethanol precipitation (see Section 2.1.1)

5. Qiaquick Gel Extraction Kit (Qiagen)

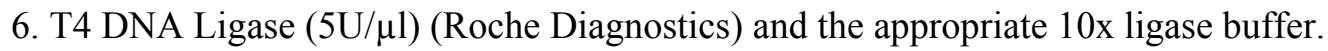

7. LB-medium: $10 \mathrm{~g}$ Bacto-Tryptone, $5 \mathrm{~g}$ Yeast extract, $5 \mathrm{~g} \mathrm{NaCl}$, qsp $\mathrm{dH}_{2} \mathrm{O}$ 1L. Autoclave.

8. Ampicillin (Roche): $100 \mathrm{mg} / \mathrm{ml}$ solution in $\mathrm{dH}_{2} \mathrm{O}$. This is a $1000 \mathrm{x}$ stock solution.

Material

1. Electroporation cuvettes

2. Electroporator E. coli Pulser (Biorad)

3. 150mm and 100mm Petri dishes of LB agar + ampicillin

4. Disposable cell scraper (Costar)

\subsubsection{Large DNA preparation and sequencing of a representative number of clones to determine}

the mutation rate

Solutions and reagents

1. $50 \%$ glycerol solution

2. Qiagen Plasmid Maxi Kit (Qiagen)

3. Library efficiency DH5 $\alpha$ chemically competent E. coli $\left(10^{8}\right)$ (Invitrogen)

4. All reagents required for a plasmid extraction $\square$ miniprep $\square$ procedure (not described here).

5. Sequencing primers.

Material 

1. $2 \mathrm{ml}$ Cryotubes (NUNC)
2. $100 \mathrm{~mm}$ Petri dishes of LB agar + ampicillin.

\subsection{Yeast transformation and yeast two-hybrid screening assay}

2.3.1. Pilot yeast two-hybrid test in MAV103 yeast strain to determine the best concentration of 3-AT Strains and plasmids

1. Yeast strain: MAV103: MATa SPAL10::URA3 leu2-3,112 trp1-901 his3D200 ura3-52 ade2-

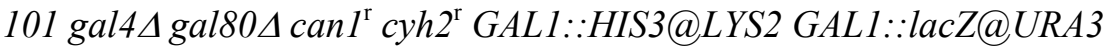

2. Bait plasmid: pPC97-GalBD Bait (Leu selection marker)

3. Prey plasmid, i.e. original aptamer plasmid: pPC86-GalAD-Thrx-aptamer (Trp selection marker)

Solutions and reagents

1. YPD medium: $10 \mathrm{~g}$ Yeast extract, $20 \mathrm{~g}$ BactPeptone, 50mg Adenine, qsp $1 \mathrm{~L} \mathrm{dH}_{2} \mathrm{O}$. Autoclave the solution. Cool down and add 100ml 20\% Glucose.

2. 1x TE: 0,01M Tris-HCl pH7.5, 1mM EDTA. Autoclave the solution.

3. 1x LiAc: 0,1M LiAc pH7.5 (pH adjusted with glacial acetic acid). Autoclave solution.

4. Li-PEG: 40\% PEG-4000 (stock solution: 50\%), 0,1M LiAc, 1x TE. Autoclave the solution.

5. Carrier DNA: salmon testes DNA 10mg/ml (Sigma), boiled and kept on ice.

6. SD medium: 2g Yeast Nitrogen Base, 5g NH4SO4, 20g Agar. Qsp $800 \mathrm{ml} \mathrm{dH}_{2} \mathrm{O}$. Autoclave. Then add $100 \mathrm{ml}$ of $20 \%$ glucose solution. Then add $20 \mathrm{ml}$ of 50x Basic Supplement $(1 \mathrm{~g} / \mathrm{L}$ Arginine, $1.5 \mathrm{~g} / \mathrm{L}$ Isoleucine, $1.5 \mathrm{~g} / \mathrm{L}$ Methionine, $2.5 \mathrm{~g} / \mathrm{L}$ Phenylalanine, $5 \mathrm{~g} / \mathrm{L}$ Threonine) (all from Sigma). Then add $10 \mathrm{ml}$ of each of the required marker amino acids depending on the selection required (see point 7).

7. Marker amino acid solutions (100x): $0.25 \%$ Histidine, $0.5 \%$ Leucine, $0.5 \%$ Lysine, $0.5 \%$ Tryptophane, $0.25 \%$ Uracile, $0.25 \%$ Adenine (all from Sigma).

8. 1M 3-AT (3-amino-1,2,4-triazole) solution (Sigma)

9. SD -Leu -Trp medium: SD medium as above, in which 10ml of each of the marker amino acid solutions are added, except Leucine and Tryptophane. 
10. SD-Leu -Trp -His + 3-AT: SD medium as above, in which 10ml of each of the marker amino acid solutions are added, except Leucine, Tryptophane and Histidine. In addition, 3-AT is added at final concentration of 20 to $120 \mathrm{mM}$.

\subsubsection{Large scale transformation of mutant peptide aptamer library}

Strains and plasmids

1. Yeast strain: MAV103: MATa SPAL10::URA3 leu2-3,112 trp1-901 his3D200 ura3-52 ade2-

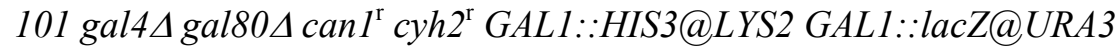

2. Bait plasmid: pPC97-GalBD Bait (Leu selection marker)

3. Library (see Section 2.2) inserted in pPC86-Gal4AD-Thrx plasmid (Trp selection marker).

Reporter gene: His

Solutions and reagents

1. YPD medium

2. SD-Leu selective medium

3. All solutions and reagents for yeast transformation ( see Section 2.3.1).

4. SD-Leu-Trp selective medium

9. 1M 3-AT (3-amino-1,2,4 triazole) solution (Sigma)

Material

1. Velvets for replica plating

2. 150mm SD-Leu-Trp agar plates

3. 150mm SD-Leu-Trp-His $+80 \mathrm{mM}$ (or $120 \mathrm{mM}$ ) 3-AT agar plates

\subsection{Isolation of high affinity clones and inhibition test in vitro}

\subsubsection{Isolation of positive clones from yeast}

Solutions and reagents

1. SD-Trp selective medium

2. Yeast extraction buffer (YEB): $10 \mathrm{mM}$ Tris- $\mathrm{HCl} \mathrm{pH} 8.0,100 \mathrm{mM} \mathrm{NaCl}, 1 \mathrm{mM}$ EDTA, $2 \%$ Triton-X100, 1\% SDS. 
3. Phenol:chloroform:isoamyl alcohol mix: 25:24:1 (Biosolve Ltd, The Netherlands)

4. Phenol/Chloroform (Invitrogen)

6. Acid washed glass beads (Sigma)

7. $95 \%$ ethanol and $70 \%$ ethanol

8. Library efficiency DH5 $\alpha$ chemically competent E. coli $\left(10^{8}\right)$ (Invitrogen)

9. $\mathrm{LB}$ medium + ampicillin $(0.1 \mathrm{mg} / \mathrm{ml})$

Material

1. Wooden toothpicks, autoclaved.

2. LB agar plates + ampicillin $(0.1 \mathrm{mg} / \mathrm{ml})$

\subsubsection{Re-transformation into yeast to confirm interaction}

Solutions and reagents

1. All solutions and reagents for LiAC yeast transformation (see Section 2.3.1.)

2. SD-Leu-Trp agar plates

3. SD-Leu-Trp-His $+80-120 \mathrm{mM}$ 3-AT agar plates

Material

1. Velvets for replica plating

\subsubsection{Sequencing of clones}

1. Clones are sent to Eurofins MWG Company for sequencing

\subsubsection{Processing of clones for in vitro inhibition assay}

Subcloning of the selected aptamers into the $p G E X$ vector

Solutions and reagents

1. pGEX vector (GE Healthcare)

2. Appropriate restriction enzymes and their corresponding 10x buffers (New England Biolabs)

3. Alkaline Phosphatase (AP) $1 \mathrm{U} / \mu 1$ (Roche Diagnostics) + 10x dephosphorylation buffer

4. Qiaquick Gel extraction Kit (Qiagen)

5. Reagents for ligation (see Section 2.2.1.)

6. Sequencing primer for pGEX plasmid: pGEX 5 primer: 5 GGGCTGGCAAGCCACGTTTGGTG-3 pGEX 3 primer: 5־CCGGGAGCTGCATGTGTCAGAGG-3 
7. Library efficiency DH5 $\alpha$ chemically competent E. coli $\left(10^{8}\right)$ (Invitrogen)

Production of recombinant proteins

Solutions and reagents

1. LB-medium + ampicillin $(0.1 \mathrm{mg} / \mathrm{ml})$

2. IPTG (Isopropyl- $\beta$-D-thiogalactopyranoside; Euromedex): $1 \mathrm{M}$ solution in $\mathrm{dH}_{2} \mathrm{O}$.

3. Glutathione Sepharose beads (GE Healthcare)

4. Lysis buffer: $50 \mathrm{mM}$ Tris $\mathrm{pH} 7.5,50 \mathrm{mM} \mathrm{NaCl}, 5 \mathrm{mM} \mathrm{MgCl}_{2}, 1 \mathrm{mM}$ DTT, $1 \mathrm{mM}$ AEBSF, $1 \mathrm{mg} / \mathrm{ml}$ leupeptin/aprotinin. For GST-GTPase production, add 10 $\mu \mathrm{M}$ GDP to this buffer.

5. Elution Buffer: 20mM Tris-HCl pH 8.0, reduced Glutathione 10mM (Sigma). Buffer to $\mathrm{pH}$ 8.0 with $\mathrm{NaOH}$. For GST-GTPase production, add $10 \mu \mathrm{M}$ GDP, $2 \mathrm{mM} \mathrm{MgCl}_{2}$ to this buffer.

6. 10\% SDS-PAGE gel and required running buffer

8. $50 \%$ Glycerol solution.

Material

1. Round centrifuge tubes ( $50 \mathrm{ml}$ capacity) (Nalgene)

2. Sonicator

3. Standard SDS PAGE gel electrophoresis material.

\subsubsection{In vitro guanine nucleotide exchange assay}

Solutions and reagents

1. Loading buffer: $20 \mathrm{mM}$ Tris-HCl pH7.5, $50 \mathrm{mM} \mathrm{NaCl}, 2 \mathrm{mM} \mathrm{MgCl}_{2}, 1 \mathrm{mM}$ DTT, $50 \mu \mathrm{g} / \mathrm{ml}$

BSA, $1 \mu \mathrm{M}$ mant-GTP (N-methylanthraniloyl fluorophore; Molecular Probes)

Material

1. 96 well-plates (Greiner Bio-One)

2. FLX800 Microplate Fluorescence Reader (BioTek Instruments) 


\section{Methods}

\subsection{PCR-based random mutagenesis}

\subsubsection{PCR-based mutagenesis}

The mutagenic PCR is performed starting with 1ng of template plasmid DNA of the aptamer of interest and using specific conditions, in order to maximize misincorporation of base pairs (see Introduction). The detailed protocol is described in Figure 3.

- $\quad 7 \mathrm{mM} \mathrm{MgCl} 2$ is used to stabilize non-complementary base pairs.

- $\quad 640 \mu \mathrm{M} \mathrm{MnCl}_{2}$ is added to diminish the template specificity of the Taq DNA polymerase.

- $1 \mathrm{mM} \mathrm{dCTP}$ and dTTP are used to promote misincorporation, while dATP and dGTP are kept at $0.2 \mathrm{mM}$.

- $\quad$ Two times excess (5 units/ reaction) Taq DNA polymerase is added to promote chain-extension beyond positions of base mismatch.

- $\quad$ Finally, serial dilutions between PCR cycles are performed to avoid predominance of a given mutation.

In order to maximize the variation of the introduced mutations, at least six independent mutagenesis PCRs are performed in parallel and are then pooled prior to the next step (PCRamplification, Section 3.1.2) (see Note 1). Using these PCR conditions, we have obtained a mean mutation rate of 3.2 mutations/peptide (range from 1 to 6 ), which is sufficient to obtain a satisfactory panel of diverse peptides (as determined by sequencing a representative number of fragments) (see Note 2).

To minimize the final volume of the pooled PCR products, it is recommended to ethanol precipitate them prior to amplification.

1. Add of $1 / 10$ volume of $3 \mathrm{M}$ sodium acetate $\mathrm{pH} 5.2$ and 2.5 volumes of ice cold $100 \%$ ethanol.

2. Mix well and place at $-20^{\circ} \mathrm{C}$ for $>20$ minutes.

3. Spin at maximum speed in a microfuge for $10-15 \mathrm{~min}$.

4. Carefully decant the supernatant and add $1 \mathrm{ml} 70 \%$ ethanol.

5. Mix well and spin briefly. Carefully decant the supernatant. 
6. Air dry or briefly vacuum the dry pellet. Resuspend the pellet in $50 \mu 1$ water.

\subsubsection{PCR-amplification of mutated inserts}

Following this PCR, which should yield up to 300 ng of pooled mutagenized peptide DNA (in $50 \mu 1$ final volume), a classical PCR is performed, in order to amplify the mutated inserts. Five PCRs are performed in parallel, each done with $10 \mu 1$ PCR product:

1. Mix $10 \mu 1$ of mutagenized PCR product with $5 \mu 110 x$ Pfu polymerase buffer, $1 \mu 1 \mathrm{dNTP}$ mix (10mM), $5 \mu 15$ primer $2 \mu \mathrm{M}, 5 \mu 13$ primer $2 \mu \mathrm{M}, 1 \mu 1 \mathrm{Pfu}$. Complete to $50 \mu 1$ with $\mathrm{dH}_{2} \mathrm{O}$.

2. PCR cycles: $95^{\circ} \mathrm{C} 5 \mathrm{~min}, 95^{\circ} \mathrm{C} 30 \mathrm{sec}, 51^{\circ} \mathrm{C} 1 \mathrm{~min}, 72^{\circ} \mathrm{C} 1 \mathrm{~min},(40$ cycles $), 72^{\circ} \mathrm{C} 10 \mathrm{~min}$.

3. Check an aliquot of the PCR on a $2 \%$ agarose gel, in order to verify efficient amplification of the mutagenized DNA.

The PCR products are then pooled again in an eppendorf tube, and digested with the appropriate restriction enzymes, in order to create cohesive ends, for subsequent cloning into the prey plasmid pPC86-Gal4AD-Thrx (see Section 3.2.1. for vector preparation).

1. To $250 \mu 1$ PCR products, add $40 \mu 110 x$ enzyme buffer $+5 \mu 1$ of each enzyme, qsp $400 \mu 1 \mathrm{dH}_{2} \mathrm{O}$.

2. Incubate $2 \mathrm{~h}$ at $37^{\circ} \mathrm{C}$, then load all on a $2 \%$ agarose gel, and purify DNA fragment-containing agarose bit using Qiaquick Gel extraction Kit according to manufacturer $\$ instructions (Qiagen). Elute from column twice with $40 \mu 1 \mathrm{H}_{2} \mathrm{O}$.

3. Load $1 \mu 1$ of purified insert on a $2 \%$ agarose gel, to check the size and concentration of the insert.

\subsection{Construction of mutant aptamer yeast library}

\subsubsection{Ligation and large scale transformation into competent E.coli} pPC86-Gal4AD-Thrx vector preparation.

1. Cut $20 \mu \mathrm{g}$ vector in $300 \mu 1$ final volume, with $30 \mu 1$ 10x enzyme buffer $+5 \mu 1$ of each enzyme.

2. Incubate $2 \mathrm{~h}$ at $37^{\circ} \mathrm{C}$, then load all on a $2 \%$ agarose gel, and purify vector containing agarose fragment using Qiaquick Gel extraction Kit according to manufacturer s instructions (Qiagen). Perform two successive elutions from the same column $(2 \times 50 \mu 1)$ 
3. Dephosphorylate vector ends using alkaline phosphatase. Add 10 $\mu 110 x$ AP buffer directly into the eluted vector and add $2 \mu 1 \mathrm{AP}$.

4. Incubate $20 \mathrm{~min}$ at $37^{\circ} \mathrm{C}$, then add $2 \mu \mathrm{AP}$ again and incubate 10 more minutes.

5. Heat inactivate the AP by adding $20 \mathrm{mM}$ EGTA (final concentration) and incubating for 10 $\min$ at $65^{\circ} \mathrm{C}$.

6. Phenol-chloroform extract vector DNA by adding 1 volume phenol/chloroform (see Note 3), vortexing and spinning for $5 \mathrm{~min}$ at full speed in a microfuge.

7. Transfer the upper aqueous phase into a new tube and add 1 volume of chloroform. Vortex and spin again as above.

8. Ethanol precipitate the supernatant by proceeding as above (Section 3.1.1, point 1-6).

9. Purify again this DNA suspension on a Qiaquick column, and elute in $50 \mu 1 \mathrm{H}_{2} \mathrm{O}$.

10. Check $1 \mu 1$ of purified vector on a $1 \%$ agarose gel, to check size and concentration of vector (see Note 4). For best results, aim at obtaining at least a concentration of $200 \mathrm{ng} / \mu 1$ of vector.

Ligation. The ligation is performed as many independent ligation reactions, to obtain the maximum possible representation of clones. Reactions are then pooled to transform competent $E$. coli. The vector/insert molar ratio should be 1:3 (or up to 1:5).

1. Prepare 40 eppendorf tubes, each one containing the following mix: 200 ng vector, $10-20$ ng insert (purified PCR products of Section 3.1.2.), $1 \mu 1$ 10x ligation buffer, $1 \mu$ l high conc ligase, qsp $10 \mu 1 \mathrm{H}_{2} \mathrm{O}$ (see Note 5).

2. Prepare one additional tube (negative control) containing the same mix as above except insert DNA.

3. Incubate these ligation mixes at $12^{\circ} \mathrm{C}$, overnight in a water bath (see Note 6).

Transformation of ligation mixes into ultra competent E. coli.

1. Before transforming into bacteria, the ligation reactions should be pooled and precipitated with ethanol, using the protocol described in Section 3.1.1 (points 1-6). Resuspend in $200 \mu 1$ final volume $\mathrm{H}_{2} \mathrm{O}$ (see Note 7).

2. Transform ultra electro-competent E.coli (EP Max $10^{10}$ ) (Biorad), which have revealed the most efficient in our hands for this purpose. Transform $40 \times 5 \mu 1$ of the precipitated ligation mix 
( $+5 \mu 1$ of the control ligation) into $41 \times 50 \mu 1$ bacteria, according to the manufacturer 5 instructions.

3. For plating of the transformed bacteria, prepare 20 large $150 \mathrm{~mm}$ plates of LB agar + ampicillin $(0.1 \mathrm{mg} / \mathrm{ml})$. Plate two tubes on the same plate.

4. In parallel, plate $1 / 500$ and $1 / 1000$ of a transformation on two $100 \mathrm{~mm}$ LB agar + ampicillin plates ( + the negative control). These plates will serve for counting of the number of transformants, i.e. for determining the number of clones contained in the library (see Note 8).

5. Let grow overnight at $37^{\circ} \mathrm{C}$.

6. The next day, a lawn of bacteria should have grown on each plate, and no colony should have appeared on the control plate. Using a cell scraper, scrape off this lawn from each plate in 510ml LB and collect the bacterial suspension in a sterile flask. This yields approximately $250 \mathrm{ml}$ of suspension. This can further be diluted with fresh LB + ampicillin for better growth results, up to $500 \mathrm{ml}$ final volume.

7. Let this culture grow over night in a shaking incubator at $37^{\circ} \mathrm{C}$.

\subsubsection{Large DNA preparation and sequencing of a representative number of clones to}

\section{determine the mutation rate}

1. Before proceeding to the plasmid DNA extraction, it is advisory to remove a $100 \mathrm{ml}$ aliquot of the above culture and to freeze down glycerol stocks of the library in cryotubes (in $20 \%$ glycerol). Store the tubes (approximately 100 ) at $-80^{\circ} \mathrm{C}$.

2. Split the rest of the culture into $4 \mathrm{x} 100 \mathrm{ml}$ and proceed with the DNA extraction using 4 columns of the Qiagen MAXIprep Kit, according to manufacturer instructions. In total, this yields at least $1 \mathrm{mg}$ library plasmid DNA, at $1 \mu \mathrm{g} / \mu \mathrm{l}$.

3. At this stage, it is crucial to verify the successful creation of the library. To do so, $1 \mu \mathrm{g}$ of library plasmid DNA is transformed into classical DH5 $\alpha$ bacteria, plated on LB agar + ampicillin, and 24 DNA minipreps are prepared from picked single colonies. These are sent to sequencing.

\subsection{Yeast transformation and yeast two-hybrid screening assay}




\subsubsection{Pilot yeast-two hybrid test in MAV103 yeast strain to determine the best concentration of}

\section{3-AT drug}

The optimization strategy described in this chapter relies on the rationale that stronger binding of the peptides to the bait in yeast will also lead to stronger inhibition. Therefore the yeast screening is performed on selective medium (for both bait and prey, i.e. SD-Leu-Trp) to which the drug 3-AT is added, which prevents Histidine synthesis. Thus only strong interactors, which strongly activate the Histidine reporter gene, will allow yeast to grow. The concentration of 3-AT to be used varies for each peptide/bait couple, and has to be determined in a yeast transformation assay prior to the actual large scale mutant peptide library screening. A concentration should be chosen at which no interaction with the original aptamer is detected anymore.

\section{Classical yeast transformation:}

1. Day 0: set up a 10ml culture of MAV103 yeast in YPD medium in a 50ml Falcon tube, and let grow overnight in a $30^{\circ} \mathrm{C}$ shaking incubator.

2. Day 1: dilute the starter to $1 / 20$ in the required volume of YPD (see point 5) and let grow to early $\log$ phase, i.e. $\mathrm{OD}_{600 \mathrm{~nm}}$ of $0.4-0.5$, which corresponds to $5-7 \times 10^{6}$ cells $/ \mathrm{ml}$.

3. Spin down yeasts in $50 \mathrm{ml}$ Falcon tubes, 4 min at 3000rpm, at room temperature.

4. Wash the pellet once with sterile $\mathrm{dH}_{2} \mathrm{O}$ and pool everything in one tube.

5. Spin again as above and resuspend the pellet in $0.1 \mathrm{M} \mathrm{LiAc-TE}$, at a concentration of $5 \times 10^{8}$ cells $/ \mathrm{ml}$. The volume depends on the number of transformations that have to be done. $100 \mu 1$ of this yeast suspension is required per transformation. So when setting up the yeast culture, plan enough volume to have enough of the final suspension at $5 \times 10^{8}$ cells $/ \mathrm{ml}$.

6. Prepare as many $1.5 \mathrm{ml}$ eppendorf tubes as required, containing $2 \mu \mathrm{g}$ of the DNA to be transformed (up to $10 \mu 1$ volume) and $4 \mu 1$ of carrier DNA. Classical transformation conditions include a negative control (no DNA), the bait plasmid alone, the prey peptide plasmid alone, and bait/peptide plasmids together.

7. Add $100 \mu l$ per tube of the yeast suspension of point 5 .

8. Add $600 \mu 1 \mathrm{Li}-\mathrm{PEG}$ solution and mix by flicking the tube several times until a homogenous suspension is obtained (see Note 9). 
9. Incubate the tubes for $30 \mathrm{~min}$ at $30^{\circ} \mathrm{C}$. In the meantime pre-heat a water bath to $42^{\circ} \mathrm{C}$.

10. Perform the heat-shock for $10 \mathrm{~min}$ at $42^{\circ} \mathrm{C}$.

11. Spin yeast briefly in a microfuge ( $5 \mathrm{sec}$, full speed).

12. Wash the pellet with 1xTE by pipetting up and down and spin again as above.

13. Finally, resuspend the pellet in $150 \mu 11 \mathrm{xTE}$ and spread all on SD-Leu-Trp selective plates. Plates are then incubated for 3 days in a $30^{\circ} \mathrm{C}$ incubator.

Replica plating of grown colonies on selective medium containing increasing concentrations of 3-AT.

1. Prepare SD-Leu-Trp-His agar plates, containing increasing concentration of 3-AT (see Note 10). Starting from a $1 \mathrm{M}$ stock solution of 3-AT, dilute accordingly to obtain plates containing 0, 20, 40, 60, 80, 100, $120 \mathrm{mM} 3-\mathrm{AT}$.

2. Replica plate the colonies grown on SD-Leu-Trp plates on each of these plates and incubate at $30^{\circ} \mathrm{C}$, until colonies appear (3-4 days).

3. Chose the concentration of 3-AT to be used for the large scale screening by determining the plates on which no colonies grow, i.e. at which no interaction with the original aptamer is detected anymore (see Note 11).

\subsubsection{Large scale transformation of mutant peptide aptamer library.}

For the large scale yeast transformation with the created mutant peptide library, transformation efficiency is critical, in order to obtain a maximum number of transformants. Therefore it is recommended to transform yeast sequentially, i.e. first with the bait plasmid alone, and subsequently with the library. This has been shown to significantly increase transformation efficiency.

1. Transform MAV103 yeast with pPC97-GalBD Bait plasmid using the protocol detailed in section 3.1.1, and plate on SD-Leu selective medium. Plates are then incubated for 3 days in a $30^{\circ} \mathrm{C}$ incubator.

2. Pick one colony from this plate (MAV103-pPC97-Bait) and inoculate a 100ml culture in SDLeu medium, as a starting culture for the large scale transformation. 
3. Large scale yeast transformation: this transformation basically consists in a many fold of single transformations, using the classical yeast transformation protocol described in section 3.1.1, with the slight modifications described below.

4. Dilute the starter to $1 / 20$ in $1000 \mathrm{ml}$ of SD-Leu selective medium in an appropriate flask and let grow to early $\log$ phase, i.e. $\mathrm{OD}_{600 \mathrm{~nm}}$ of $0.4-0.5$, which corresponds to $1-2 \times 10^{6}$ cells $/ \mathrm{ml}$ (in synthetic medium).

5. Centrifuge and wash the yeast cells as above and resuspend them in $4.2 \mathrm{ml} 0.1 \mathrm{M} \mathrm{LiAc-TE}$. This gives a cell suspension of $5 \times 10^{8}$ cells $/ \mathrm{ml}$.

6. Prepare 42 eppendorf tubes:

40 tubes: each containing $10 \mu 1$ of the mutant peptide library (in the pPC86-Gal4AD-Thrx vector) (see Section 3.2) and $4 \mu 1$ of carrier DNA.

1 tube containing no DNA and 1 tube containing the original pPC86 - wt aptamer plasmid and $4 \mu 1$ of carrier DNA.

7. For the rest of the protocol, proceed as in Section 3.3.1. (points 7-13), except that after resuspending the yeast pellet in $150 \mu 11 \mathrm{xTE}, 8$ tubes are pooled together and plated on $150 \mathrm{~mm}$ SD-Leu-Trp selective plates (5 plates total) (see Note 12). The control transformations are processed as above, and plated on $100 \mathrm{~mm}$ plates of the same medium.

Using this procedure, we screened approximately $3 \times 10^{5}$ clones.

8. Five days after plating, yeasts are replica plated on SD-Leu-Trp-His selective plates, containing the concentration of 3-AT determined in the pilot yeast assay (in our case $80 \mathrm{mM}$ and $120 \mathrm{mM}$ ).

\subsection{Isolation of high affinity clones and inhibition test in vitro}

\subsubsection{Isolation of positive clones from yeast}

1. Pick colonies that grew on the plates containing $80 \mathrm{mM}$ and $120 \mathrm{mM} 3-\mathrm{AT}$, respectively.

2. Grow small cultures of each picked colony overnight in a $30^{\circ} \mathrm{C}$ shaking incubator, in $2 \mathrm{ml}$ medium that maintains selection only for the prey plasmid DNA (SD-Trp) (see Note 13).

3. Fill a $1.5 \mathrm{ml}$ eppendorf tube with the culture and collect the cells by a 5 -second centrifugation in a microfuge. 
4. Discard supernatant and briefly vortex the tube to resuspend the pellet in the residual liquid.

5. Add $200 \mu 1$ of yeast extraction buffer (YEB). Add $200 \mu 1$ phenol:chloroform:isoamyl alcohol

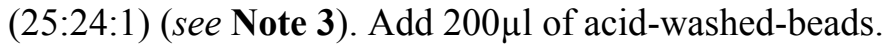

6. Vortex for 5-7 minutes and centrifuge for $5 \mathrm{~min}$ in a microfuge.

7. Collect aqueous phase and perform second phenol-chloroform extraction.

8. Vortex briefly and centrifuge again.

9. Remove $100 \mu 1$ of aqueous phase, transfer into new tube and precipitate it with Ethanol (see Note 14). Cool for $10 \mathrm{~min}$ at $-20^{\circ} \mathrm{C}$.

10. Centrifuge for $10 \mathrm{~min}$ in a microfuge, discard supernatant, wash the pellet with $200 \mu 170 \%$ Ethanol, and centrifuge again for $1 \mathrm{~min}$.

11. Discard supernatant and let pellet briefly air-dry.

12. Resuspend the pellet in $50 \mu 1 \mathrm{dH}_{2} \mathrm{O}$ and use $1 \mu 1$ to transform chemically competent E.coli, according to manufacturer 5 instructions (see Note 15), plating on LB + ampicillin.

13. Plasmid DNA is extracted from grown colonies, following standard $\square$ miniprep $\square$ procedures.

\subsubsection{Re-transformation into yeast to confirm interaction}

Using the Li-Ac yeast transformation protocol (section 3.1.1), it is important to confirm that the selected and isolated prey plasmids interact with the bait on the stringent 3-AT medium. Proceed as described in section 3.1.2 for replica plating.

\subsubsection{Sequencing of clones}

Positive clones, whose strong binding to bait protein under stringent conditions has been confirmed upon re-transformation in yeast, are then sequenced to determine the mutated codon and deduced amino acid sequence. 60 clones is a reasonable number to start with, considering possible redundancy and subsequent processing of clones. Two micrograms plasmid DNA from a miniprep are sent to sequencing, together with the appropriate $5 \square$ primer.

\subsubsection{Processing of clones for in vitro inhibition assay}

After sequencing and chosing the clones of interest, aptamers should be further processed in order to test them in the relevant biological assay. In the example we present here, aptamers are 
produced as recombinant proteins and subsequently tested in an in vitro guanine nucleotide exchange assay, with recombinant RhoA GTPase and Tgat GEF.

\section{Subcloning of the selected aptamers into the $p G E X$ vector}

Aptamer inserts are subcloned into the pGEX-5X bacterial expression vector, for further recombinant protein production, using classical subcloning procedures. Briefly:

1. In an eppendorf tube, digest plasmid DNA pPC86-Aptamer-X with appropriate restriction enzymes to cut out insert: $20 \mu 1$ DNA (of a miniprep) $+5 \mu 1$ 10X enzyme buffer $+1 \mu 1$ of each enzyme, qsp $50 \mu 1 \mathrm{dH}_{2} \mathrm{O}$.

2. In parallel, digest pGEX-5X1 vector with appropriate restriction enzymes to linearize vector: $5 \mu \mathrm{g}$ DNA $+5 \mu 110 \mathrm{X}$ enzyme buffer $+1 \mu 1$ of each enzyme, qsp $50 \mu 1 \mathrm{dH}_{2} \mathrm{O}$.

3. Incubate $1 \mathrm{~h}$ to $2 \mathrm{~h}$ at $37^{\circ} \mathrm{C}$, and verify $5 \mu \mathrm{l}$ on a $1 \%$ agarose gel, to check for correct linearization of the vector and correct size of the insert.

4. Dephosphorylate vector ends using alkaline phosphatase. Add $6 \mu 1$ 10x AP buffer directly into the digestion reaction $+1.5 \mu \mathrm{l}$ AP.

5. Incubate $20 \mathrm{~min}$ at $37^{\circ} \mathrm{C}$, then add $0.5 \mu \mathrm{AP}$ again and incubate 10 more minutes.

6. Load both vector and insert on an agarose gel, and purify DNA containing agarose fragment using the Qiaquick Gel extraction Kit according to the manufacturer $\widetilde{S}$ instructions. Elute the insert in $30 \mu 1 \mathrm{H}_{2} \mathrm{O}$ and the vector in $50 \mu 1$.

7. Check $1 \mu l$ of the purified insert and vector on an agarose gel, to check the size and concentration.

8. Purified vector and inserts are then ligated together, at a molar ratio of 1:3 (estimation on agarose gel is sufficient). Final volume of reaction: $10 \mu 1$. Mix all reagents on ice.

9. Incubate ligation reaction at $12^{\circ} \mathrm{C}$ in a water bath for at least $4 \mathrm{~h}$, better overnight.

10. Ligation reactions are then transformed into chemically competent E.coli $\mathrm{DH} 5 \alpha$, according to manufacturer 5 instructions, and plated on LB + ampicillin plates.

11. Plasmid DNA extraction $\square$ minipreps $\square$ are performed on colonies picked from the plates.

12. Positive clones are then sent to sequencing with the pGEX5 $\square$ primer, to verify the correct in frame insertion of the insert. 
Production of recombinant proteins. GST-GEFs and GST-GTPases are produced using the standard protocol described below, except that GTPases are produced and eluted in the constant presence of $10 \mu \mathrm{M}$ GDP and $2 \mathrm{mM} \mathrm{MgCl}_{2}$ in the buffer (= GDP-loaded GTPase)

1. Set up $50 \mathrm{ml}$ preculture in $\mathrm{LB}+$ ampicillin overnight at $37^{\circ} \mathrm{C}$, in a shaking incubator.

2. Dilute the starter in $1 \mathrm{~L} \mathrm{LB}+$ ampicillin, in a large flask. Grow at $37^{\circ} \mathrm{C}$ in a shaking incubator until $\mathrm{OD}_{600 \mathrm{~nm}}$ of 0.8 (up to 1 ) is reached. Add IPTG to $0.1 \mathrm{mM}$ final concentration to induce protein production, and incubate $3 \mathrm{~h}$ at $20^{\circ} \mathrm{C}$, in a shaking incubator.

3. Spin at $3750 \mathrm{rpm}$ for $15 \mathrm{~min}, 4^{\circ} \mathrm{C}$ (in big buckets).

4. Resuspend the pellet in $10 \mathrm{ml} 1 \mathrm{x}$ PBS and transfer into 50ml Falcon tubes and spin again $3000 \mathrm{rpm}$ for $15 \mathrm{~min}$ at $4^{\circ} \mathrm{C}$ (see Note 16).

5. Resuspend the pellet in $10 \mathrm{ml}$ ice cold lysis buffer, transfer into 50ml tubes (Nalgene).

6. Sonicate $3 \times 30 \mathrm{sec}(40 \%$ intensity).

7. Centifuge for $10 \mathrm{~min}$ at $13\left[000 \mathrm{rpm}\right.$ at $4^{\circ} \mathrm{C}$.

8. Transfer the supernatant in a $50 \mathrm{ml}$ Falcon tube, on ice.

9. Resuspend the remaining pellet again in $10 \mathrm{ml}$ lysis buffer. Sonicate and centrifuge as above.

10. Collect the supernatant and pool with the first supernatant in a Falcon tube, on ice.

11. Add $350 \mu$ l Glutathione Sepharose beads (50\% slurry equilibrated in lysis buffer).

12. Leave on wheel for $30 \mathrm{~min}$ at $4^{\circ} \mathrm{C}$ and then centrifuge for $3 \mathrm{~min}$ at $3000 \mathrm{rpm}$, at $4^{\circ} \mathrm{C}$.

13. Wash pellet once with 5-10ml cold lysis buffer (without protease inhibitors and DTT).

14. Resuspend the beads in $1 \mathrm{ml}$ lysis buffer and transfer into an eppendorf tube.

15. Wash twice with $1 \mathrm{ml}$ lysis buffer, by centrifuging at $14000 \mathrm{rpm}$ for 20 seconds.

16. After the last spin, elute the bound protein by adding $400 \mu$ Elution buffer and incubating on a rotating wheel for $1 \mathrm{~h}$ at $4^{\circ} \mathrm{C}$.

17. Centrifuge as above and transfer supernatant into an eppendorf tube.

18. Check all proteins on SDS-PAGE gel together with a BSA standard, to verify correct size and concentration of the produced proteins.

19. Add glycerol to $30 \%$ final concentration and snap freeze the proteins in aliquots in liquid $\mathrm{N}_{2}$, store at $-80^{\circ} \mathrm{C}$ (see Note 17$)$. 


\subsubsection{In vitro guanine nucleotide exchange assay}

In order to evaluate the inhibitory potential towards their GEF target of the newly isolated, stronger interacting aptamers, a fluorescent guanine nucleotide exchange assay is performed, using the recombinant GST-fusion proteins produced in section 4.4.2. Nucleotide exchange is monitored by measuring mant-GTP loading on the GTPase.

1. Premix: pre-incubate GEF and aptamer in $95 \mu 1$ loading buffer containing mant-GTP. The GEF $(0.1-0.5 \mu \mathrm{M})$ is allowed to equilibrate with $20 \mu \mathrm{M}$ peptide inhibitor for $5 \mathrm{~min}$ in loading buffer containing $1 \mu \mathrm{M}$ mant-GTP, in a 96 well-plate, at $25^{\circ} \mathrm{C}$.

2. Start the reaction by adding $5 \mu 1$ of $20 \mu \mathrm{M}$ GDP-loaded GST-GTPase to the premix, in order to obtain a final concentration of $1 \mu \mathrm{M}$ GTPase, in $100 \mu 1$ final volume.

3. The exchange reaction is monitored for 15 minutes (measurements are taken every 10 seconds) by following the increase in relative fluorescence due to the loading of the fluorescent GTP analog upon binding to the GTPase at $25^{\circ} \mathrm{C}$, using a $\mathrm{FL}_{X} 800$ microplate fluorescence reader (BIO-TEK Instruments) $\left(\lambda_{\mathrm{ex}}=360 \mathrm{~nm}, \lambda_{\mathrm{em}}=460 \mathrm{~nm}\right)$.

An example of the TRIP-derived peptides we obtained that showed stronger interaction and stronger inhibition potential is shown in Figure 4. 


\section{Notes}

1. It is preferable to split the PCR master mix into different aliquots, to run these reactions separately and then to mix them together upon completion of the reaction (before the amplification PCR reaction), in order to prevent over-representation in the library of single mutations occurring in the first rounds of PCR. This will increase the diversity of the library.

2. In order to determine whether a satisfactory mutation rate has been obtained, it is advised to subclone an aliquot of the PCR fragments into the TOPO cloning vector (TOPO TA Cloning Kit for Sequencing, Invitrogen) according to the manufacturer $₫$ instructions, and to sequence a relevant number of clones, before constructing the library.

3. Phenol is highly corrosive and can cause severe burns. Chloroform is irritating to the skin, eyes, mucus membranes and upper respiratory tract. It is carcinogen and may damage liver and kidneys. Therefore, gloves, protective clothing and safety glasses should be worn when handling them, and work in a chemical hood is strongly advised.

4. Experience has shown that in order to precisely determine DNA concentration of vector (and insert), measurement on a device such as the Nanodrop is less precise than an evaluation on agarose gel, using a standard DNA as control.

5. In some cases, we have noticed that adding 5\% PEG 4000 to the ligation mix enhances ligation efficiency.

6. Incubation of the ligations at $12^{\circ} \mathrm{C}$ has proven more efficient than at $16^{\circ} \mathrm{C}$ or $4{ }^{\circ} \mathrm{C}$ or even RT.

7. Precipitation of the ligations in order to get rid of any salts contained in the reaction is crucial to avoid the formation of an electric arc when electroporating the bacteria.

8. Typically, using this protocol, we obtained a library complexity of at least $1 \times 10^{6}$.

9. Do not vortex the tubes, as PEG renders yeast fragile.

10. Caution: 3-AT is a highly toxic compound and should be handled accordingly, with all protective and safety measures.

11. In our case, $40 \mathrm{mM} 3-\mathrm{AT}$ was the highest concentration at which colony growth was observed with the initial $\square$ wild type $\square$ aptamer. Therefore we chose concentrations of $80 \mathrm{mM}$ and $120 \mathrm{mM}$ 3-AT for the large scale screening. 
12. It is recommended to plate an aliquot of the final yeast suspension ( $1 / 10$ of a $150 \mu$ l suspension) on a separate $100 \mathrm{~mm}$ selective plate. This will allow determining the transformation efficiency, by counting the number of colonies grown on this plate. In our case, we screened approximately $3 \times 10^{5}$ clones.

13. When growing yeast for plasmid DNA extraction, grow the yeast in the medium that selects only for the prey plasmid (i.e. SD-Trp), don $t$ keep the selection of the bait plasmid (Leu). This has turned out more efficient to extract prey plasmid (over bait plasmid).

14. Be careful when collecting the aqueous phase from the tube, to make sure no phenol/chloroform is contaminating the collected phase.

15. Usually, transformation into E.coli of DNA plasmid isolated from yeast gives low yields. To improve the transformation efficiency, one can use up to $5 \mu 1$ of isolated plasmid, and it is strongly recommended to use highly competent, commercially available bacteria (competence of at least $\left.10^{8}\right)$.

16. This is a good moment to freeze the bacterial pellets at $-20^{\circ} \mathrm{C}$ to do the extracts later.

17. Stability of recombinant proteins stored at $-80^{\circ} \mathrm{C}$ is highly variable and should be determined for each type of protein. Usually, they are stable for at least 1 month, and up to one year. 


\section{Acknowledgments}

We are grateful to Anne Briançon-Marjollet for her contribution to the library construction. This work was supported by grants from the ANR "Physique et chimie du vivant" grant $\mathrm{N}^{\circ} 06-137373$. N. B. was supported by a CNRS valorization fellowship from CNRS. All authors are members of the CNRS consortium GDR2823.

\section{References}

1. Colas, P., Cohen, B., Jessen, T., Grishina, I., McCoy, J., and Brent, R. (1996) Genetic selection of peptide aptamers that recognize and inhibit cyclin-dependent kinase 2, Nature $380,548-550$.

2. Crawford, M., Woodman, R., and Ko Ferrigno, P. (2003) Peptide aptamers: tools for biology and drug discovery, Brief Funct Genomic Proteomic 2, 72-79.

3. Hoppe-Seyler, F., Crnkovic-Mertens, I., Tomai, E., and Butz, K. (2004) Peptide aptamers: specific inhibitors of protein function, Curr Mol Med 4, 529-538.

4. Borghouts, C., Kunz, C., and Groner, B. (2005) Peptide aptamers: recent developments for cancer therapy, Expert Opin Biol Ther 5, 783-797.

5. Schmidt, S., Diriong, S., Mery, J., Fabbrizio, E., and Debant, A. (2002) Identification of the first Rho-GEF inhibitor, TRIPalpha, which targets the RhoA-specific GEF domain of Trio, FEBS Lett 523, 35-42.

6. Bouquier, N., Fromont, S., Zeeh, J. C., Auziol, C., Larrousse, P., Robert, B., Zeghouf, M., Cherfils, J., Debant, A., and Schmidt, S. (2009) Aptamer-derived peptides as potent inhibitors of the oncogenic RhoGEF Tgat, Chem Biol 16, 391-400.

7. Yoshizuka, N., Moriuchi, R., Mori, T., Yamada, K., Hasegawa, S., Maeda, T., Shimada, T., Yamada, Y., Kamihira, S., Tomonaga, M., and Katamine, S. (2004) An alternative transcript derived from the trio locus encodes a guanosine nucleotide exchange factor with mouse celltransforming potential, J Biol Chem 279, 43998-44004.

8. Cadwell, R. C., and Joyce, G. F. (1992) Randomization of genes by PCR mutagenesis, PCR Methods Appl 2, 28-33. 


\section{Figure titles}

Figure 1: Flow chart of the peptide aptamer optimization protocol.

Figure 2: Principle of the yeast two-hybrid screening using a strong selective drug

Figure 3: PCR-based random mutagenesis protocol

Figure 4: Example of TRIP-derived optimized peptide aptamers obtained with the method described in this chapter. 
Pilot yeast two-hybrid test: MAV103: pPC86 aptamer + pPC97 Bait Plate on increasing 3-AT concentration (range $20-150 \mathrm{mM}$ )

\section{Determine optimal concentration of 3-AT drug: No interaction with original aptamer anymore}

\section{PCR-based mutagenesis of original aptamer}

\section{PCR-amplification of mutated inserts}

Subcloning into TOPO vector

$\longrightarrow$ Sequencing of clones to evaluate obtained mutation rate

Library construction (subcloning into yeast vector pPC86

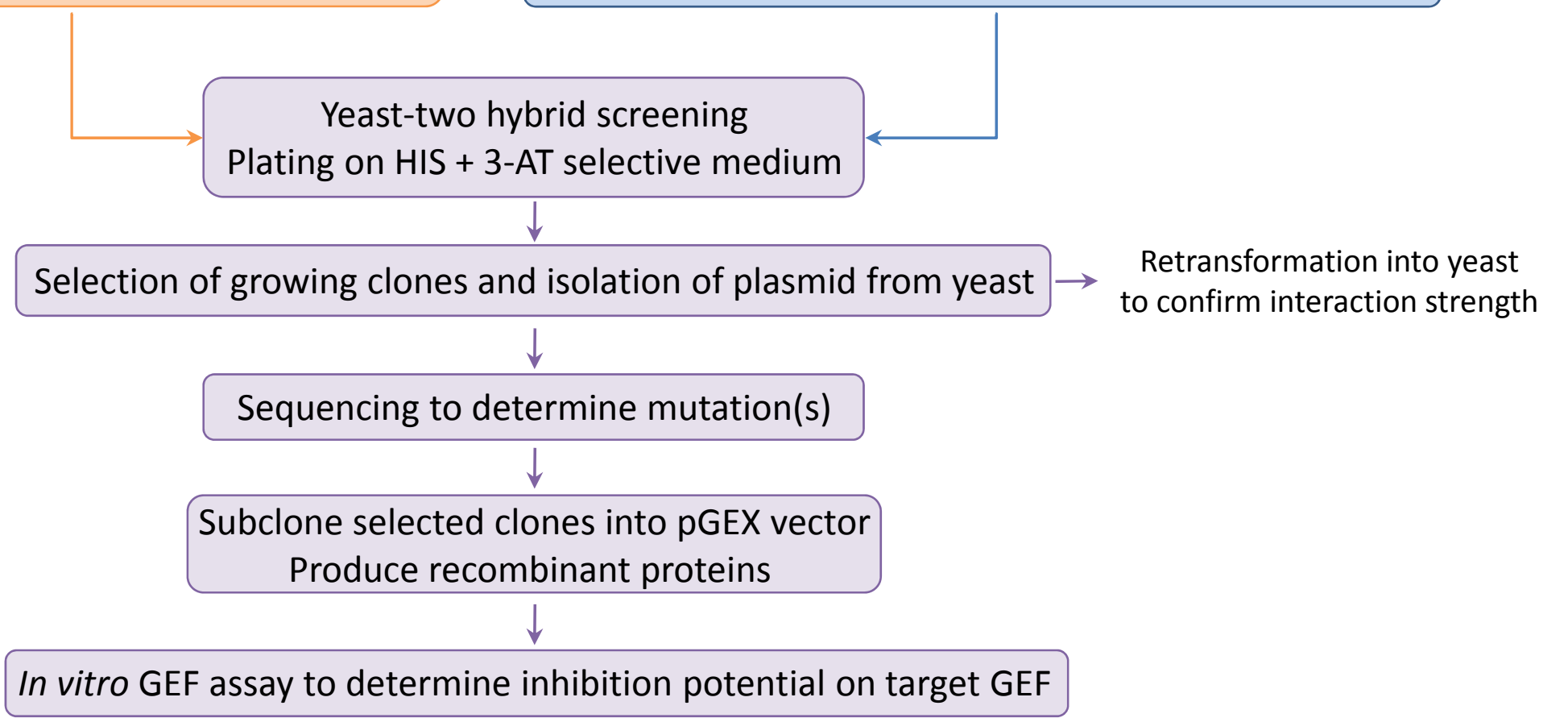



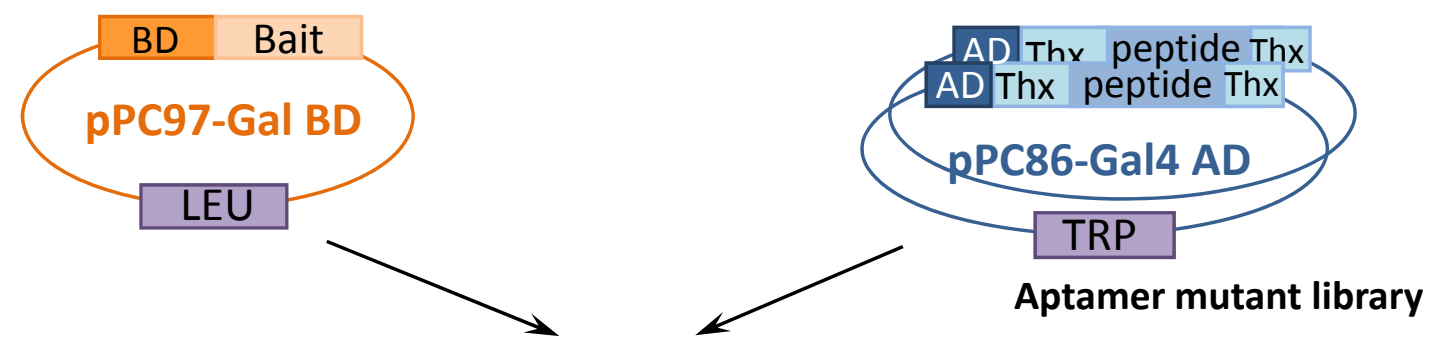

Transformation and selection

in yeast (-His-Trp-Leu)

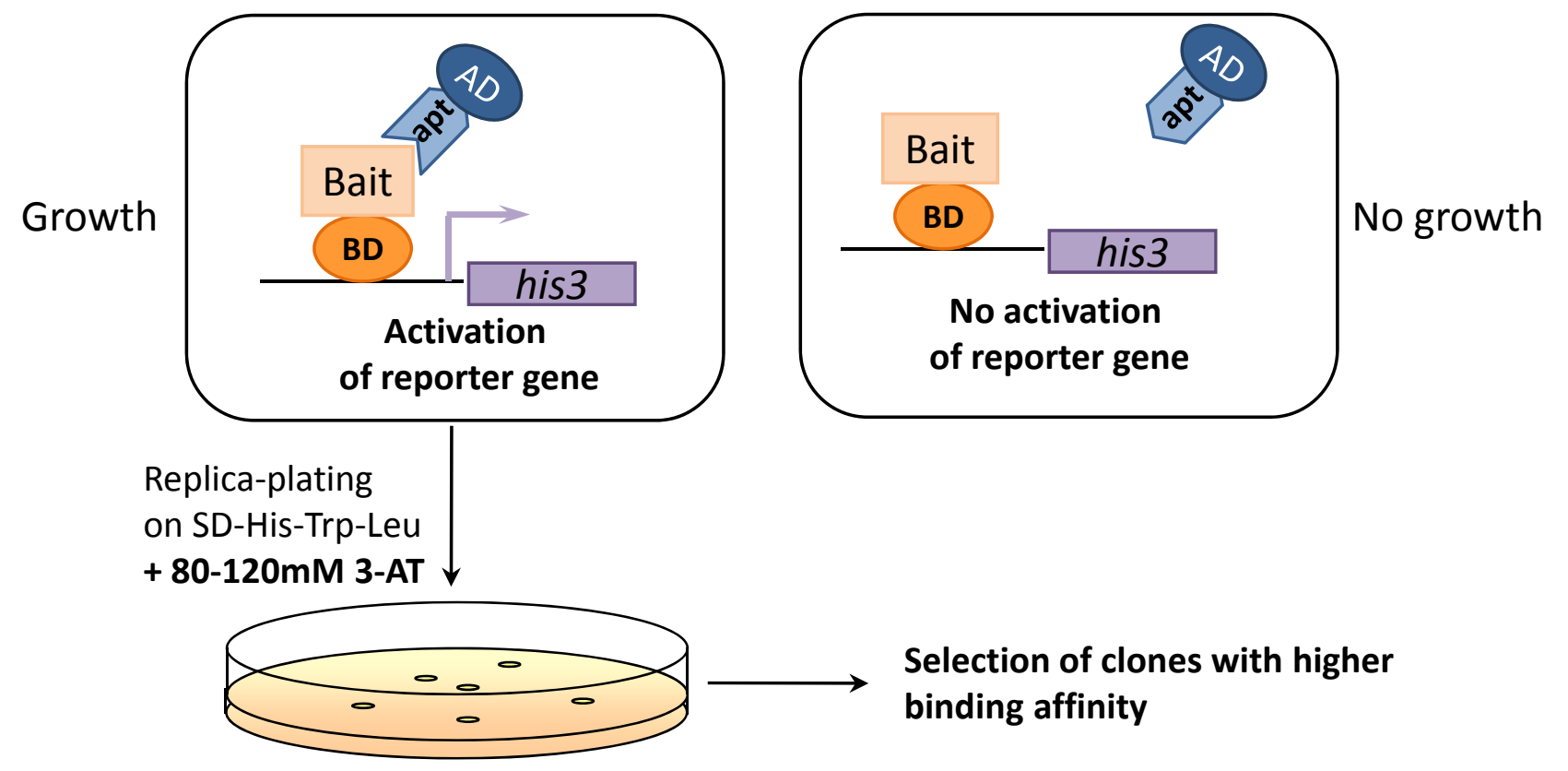




\section{PCR mix}

$76 \mu l$ PCR premix (see Materials section)

$+12 \mu \mathrm{l} \mathrm{H}_{2} \mathrm{O}$

$+10 \mu \mathrm{l} \mathrm{MgCl} / \mathrm{MnCl}_{2} \operatorname{mix}\left(50 \mathrm{mM} \mathrm{MgCl} / 6.4 \mathrm{mM} \mathrm{MnCl}_{2}\right.$ )

+1ng DNA (pPC86-aptamer plasmid)

$+1 \mu$ l Taq Polymerase

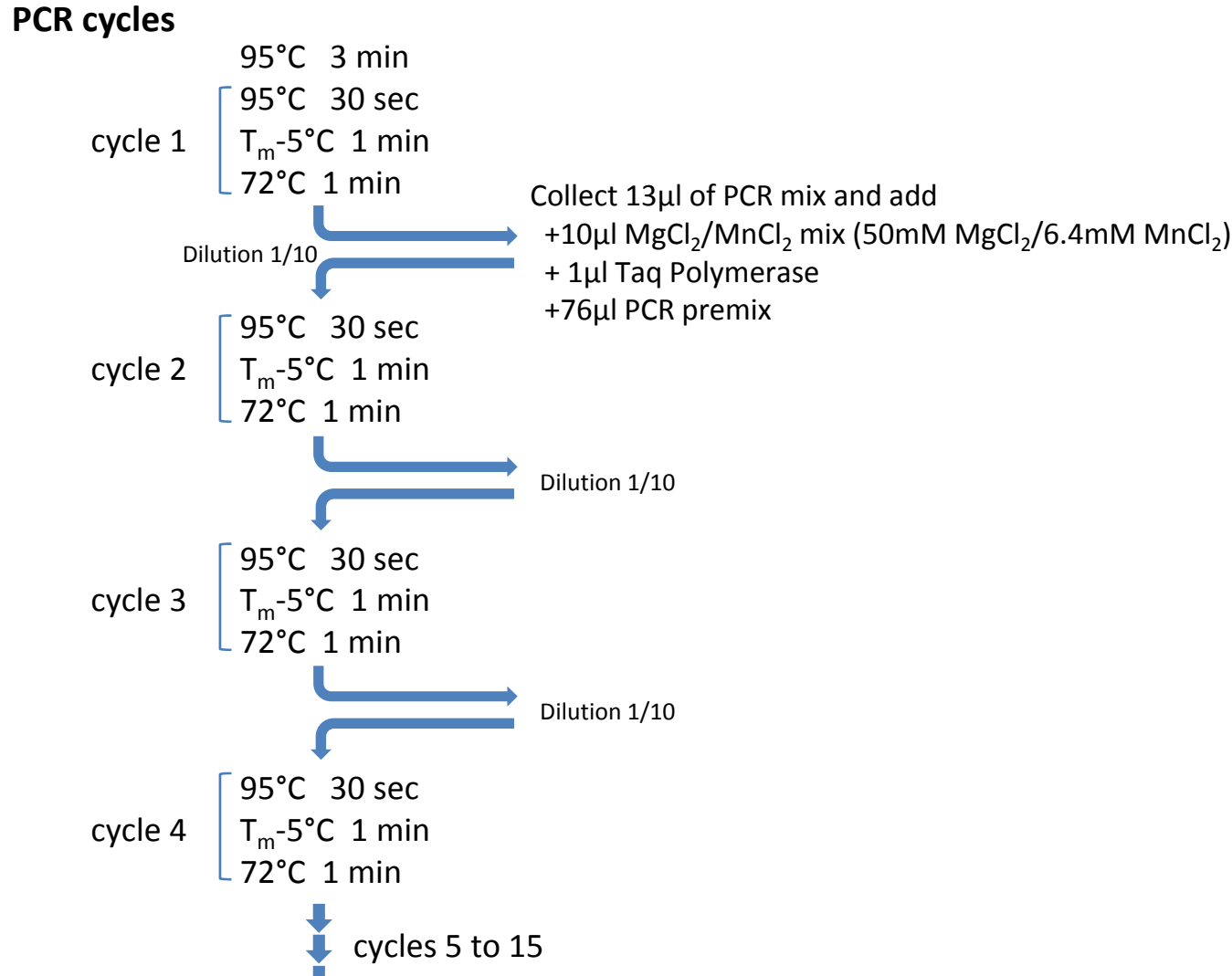

$95^{\circ} \mathrm{C} \quad 30 \mathrm{sec}$

$\mathrm{T}_{\mathrm{m}}-5^{\circ} \mathrm{C} 1 \mathrm{~min}$

$-72^{\circ} \mathrm{C} 1 \mathrm{~min}$

$\sqrt{3}$

$95^{\circ} \mathrm{C} \quad 30 \mathrm{sec}$

cycle $3 \quad \mathrm{~T}_{\mathrm{m}}-5^{\circ} \mathrm{C} 1 \mathrm{~min}$

$72^{\circ} \mathrm{C} 1 \mathrm{~min}$

cycle $4\left[\begin{array}{l}95^{\circ} \mathrm{C} \quad 30 \mathrm{sec} \\ \mathrm{T}_{\mathrm{m}}-5^{\circ} \mathrm{C} \quad 1 \mathrm{~min} \\ 72^{\circ} \mathrm{C} 1 \mathrm{~min}\end{array}\right.$

Y

cycles 5 to 15 Collect $13 \mu \mathrm{l}$ of PCR mix and add $+10 \mu \mathrm{l} \mathrm{MgCl} / \mathrm{MnCl}_{2} \operatorname{mix}\left(50 \mathrm{mM} \mathrm{MgCl}_{2} / 6.4 \mathrm{mM} \mathrm{MnCl}_{2}\right)$

$+1 \mu$ l Taq Polymerase

$+76 \mu$ I PCR premix

Dilution $1 / 10$

Final elongation: $72^{\circ} \mathrm{C} 10 \mathrm{~min}$ 


\section{Picked 64 clones}

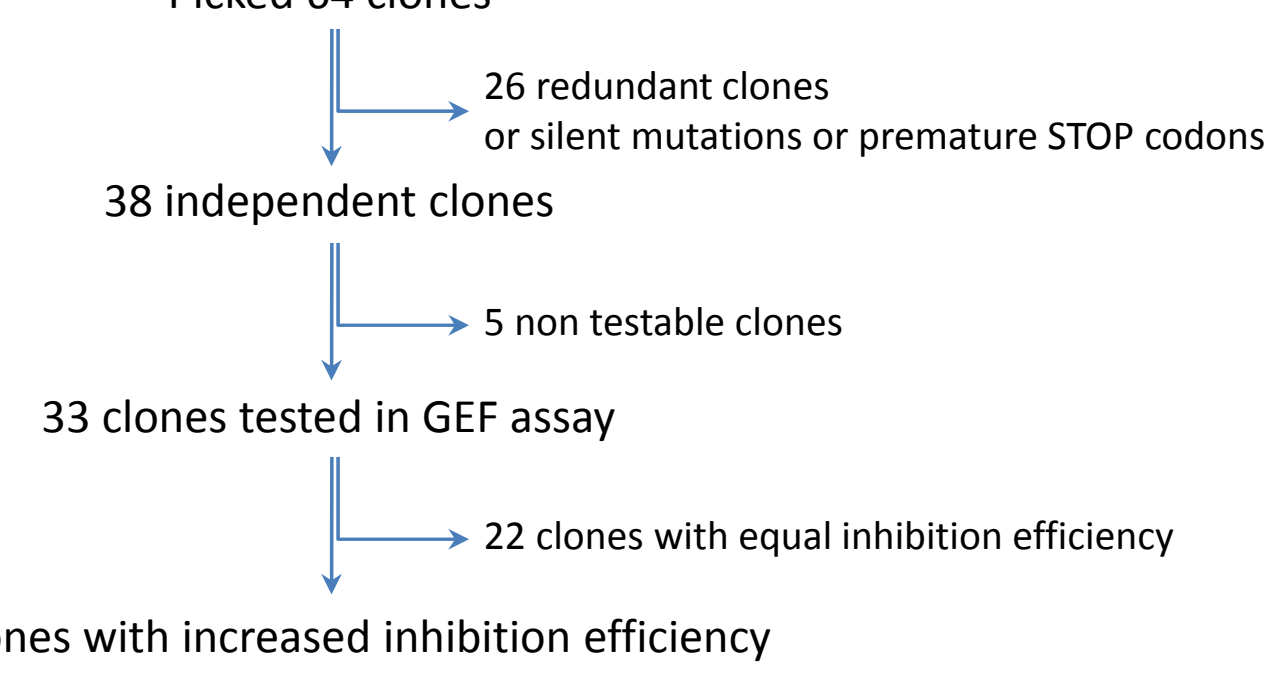

11 clones with increased inhibition efficiency

\section{PEPTIDIC SEQUENCE}

AREGADGA I C G Y N L A T L VMLGPSER V F C P L C E P C S S D I Y E L M

A R E G A D GA I C G Y N L A M S VMLGPSERVFCPLCEEPCS SDI Y E L M A REGADGA I C G Y N L A T L D MLGPSERVLC PL C E P C S S D I Y E L M A R E G A D G A I C G Y N L A T L VMLGPSERVFCPLCG P C S T D I Y E L M A R E G A D A I C G Y N L A A L GMLGPSERVFCPLCGPCSSD N Y E L M A REGADGA I C G Y D L AML VMLGPSERVFCPLCERRS A R E G A D G A I C G Y N L A T L VMLG P S E R V F C P L C G P C S S D I Y E L M A R E G A D A I C G Y N L A M L VMLGPGE R VFCPLCEPCSSD I YELM A RE GA DGA I C G Y NLATL A M L GPSARVFCPLC G P C S S D I Y E L M A REGADGA I C G Y N L A M L V MLGPSERVFCPLCEDPCS S D I Y E L M A REGADGA I C G Y N L A A S V MLGPSERVFCPL C E P R S P D I Y E E L M A R E G A D G A I C G Y N L A T L D M L GPSERVFCPLCEEPCS SD S Y E L M
MUTANT [3-AT]

$\begin{gathered}\text { Fold over TRIP } \alpha \\ \text { Inhibition }\end{gathered}$
1
$5,5 X$
$3,4 X$
$3,1 X$
$2,5 X$
$1,5 X$
$6 X$
$3,5 X$
$2,3 X$
$2 X$
$1,4 X$
$1,1 X$

